\title{
Zakat Banking: A Breakthrough Solution to Riba in Banking by Synthesising Zakat into Qardan Hasana- The Two Islamic Economic Fundamentals.
}

\author{
Abdul Malek Talib \\ Jalan Utama Johar Bahru Malaysia
}

\begin{abstract}
:
The reason why conventional banking charges interest rate to borrowers is because it has to pay interest to depositors. Islamic banking deceivingly takes adaptive reform approach to circumvent riba (interest) by substituting an interest-bearing loan into multiple trade transactions. Yet, the trade transactions are not inter-independent and "mechanically arranged" to eliminate $100 \%$ of the trading risks as banks are prohibited from trading activities in the first place. Notwithstanding this, Muslims around the globe have no other choice but to adhere to the current adaptive reform. The growth of Islamic banking shows the dire need for shariah (Islamic law) compliant products despite its shortcoming. That is the reason why many Islamic scholars are looking for a better solution in combating riba in the banking system in which the depositors gain at the borrowers expense.

This empirical analysis proposed Zakat banking to take transformational reform approach to riba in banking by synthesising zakat into qardan hasana (interest free loan). It starts with the concept that depositors are obligated to pay zakat $2.5 \%$ per annum on their deposits instead of gaining interest as in conventional banking or "profit" as in Islamic banking. Depositors then allow Zakat banking to acts as an Amil (zakat collector) to collect zakat and channels the money to the authority after deducting $1 / 8$ of the bank's entitlement. This makes Zakat banking costs of fund equal to zero; therefore, it can lend the balanced deposited pool of money to borrowers at zero rate of interest. In short, when the depositors pay zakat, the borrowers will enjoy qardan hasana.
\end{abstract}

Conversely, to make profit, Zakat banking would charge on competitive basis for the various value added payment systems such as money withdrawal, money transfer, account keeping etc. instead of relying on the interest spread between depositors and borrowers.

Keywords; Riba, Zakat, Qardan Hasana, Islamic Banking and Islamic Economic.

Corresponding Author: Abdul Malek Talib, e-mail: abdulmalek_talib@yahoo.com 


\section{Introduction}

Life in this modern sophisticated and competitive world requires a person to borrow money from banks so that they can live as others. Without borrowed money, a person will be secluded from the enjoyment and comfort of present life-style. A person needs to have a comfortable house, a car, higher education (Ahmad Hidayat, 2009). Thus, borrowing sums of money for consumption from the banks could not be avoided. Indeed, debt financing become a common practice by most people to meet the basic needs in life despite the element of riba. One would wonder why the longest ayat in the Quran is on debt (Al Baqarah: 282).

Such debt financing for comsumpton purposes is allowed in Islam but the debtor must pay back the amount he borrowed without interest. It is obligated to a person who borrowed money from another person to pay it back in full. There is a difference between lending money and giving a charity (sadaqah), in which charity is giving money without the obligation to return the same to the giver. However, debtors currently can not escape from riba practices by Conventional banking. Even in the adaptive reform approach by Islamic banking, some argue, it still contains the elements if riba. Therefore, the proposed Zakat banking should be considered to abolish riba based debt financing, where the depositors gain at the borrowers expense, by synthesising zakat into qardan hasana-the two key Islamic economic fundamentals that have been long forgotten.

In essence, riba is the outcome of capitalist economic system which believes that the right on capital is absolute; therefore, moneylenders have the full right to gain interest from borrowers. The Islamic banking manages to circumvent interest "mechanically" but trapped within the confines of the capitalist system of money lenders. On the other hand, Islamic economic system believes that money owners are obligated to pay zakat. Zakat is so important that Allah (SWT) makes it the third pillar of Islam. As such, zakat must take precedence over riba. This paper argues that to abolish riba, a revive concept of zakat must be implemented. The concept of zakat on currency must take a transformational reform as the original texts on zakat have been intrepreted within the context of agrarian economy of livestock farming and crop production. This paper attempts to present the re-evaluation of the original text in order to bring the vibrancy of zakat on currency into mordern economy and monetary system.

\section{Objective}

This article starts with the re-evaluation on current thinking and proposed Zakat banking as a transformational reform to riba in banking in response to one of the objectives of the Global Forum of Islamic Finance 2017 in Lahore that is to provide recommendation to the present Islamic banking and financial stakeholders on the future direction of Islamic banking and finance. 
In conjunction with the conference, this article also intends to present this new idea to the relevant authorities, jurists, academicians, bankers and NGOs in the possibility of creating Zakat banking in which when the depositors pay zakat then the borrowers will enjoy qardan hasana. It is by no means that zakat collection money will be used for financing rather the balanced deposited pool of money in the bank will be utilised for interest free loan.

Zakat and qardan hasana are two key fundamentals in the Islamic economy. Therefore, with the implemention of Zakat banking, it will bring Muslims closer to the ultimate objective of Islamic economy as an act of worship. Muslims believe that Islamic economic system is superior as compared to others and aspires to achieve economic growth in its own mold.

The objective of this paper is to present the conceptual framework on transformational reform approach of Zakat banking and how this new banking system works without riba. This paper also explains the implementation strategy in chapter 8 based on the famous story of well's of Saidina Uthman (R.A). As Muslims, we believe that Islamic economic system will give barakah (blessings) in this world which will spur faster and stronger economic growth. There is a need to promote fresh Islamic economic system encompassing zakat and qardan hasana and stop mimicking the habit of moneylenders of the capitalist economy.

The proposed Zakat banking is indeed a breakthrough idea not only for banking but also within the wider Islamic economic fundamentals by upholding zakat to take precedence over riba in the monetary system and bring back qardan hasana that has been entirely obliterated by the Islamic banking.

\section{Riba}

There are enough definitions for the word riba by scholars, but for a person to understand the word riba, one needs to revisit and get clearer perspective view on these four Quranic words in one go; riba, trade, loan and charity even though it might be trivial.

\subsection{Riba}

Riba is strictly prohibited in Islam. In the science of jurisprudence (Fiqh), there are three types of riba, which are as follows:

a) Riba fadhlu; It is called as usury Buyu', which is riba that arises from the exchange of two similar goods of different quality or quantity, and similar in terms of the time of giving and taking the goods.

b) Riba An-Nasi'ah; It is called as riba Duyun, which is riba that arising from debts that do not meet the criteria of profit appears with its risk, and the result of an effort appears with costs. Such transactions consists of the exchange of the 
obligation to bear the burden, just because time passes.

c) Riba Jahiliyyah; It is a debt which is paid in addition to the money borrowed because the borrower was unable to repay the loan at a predetermined time.

In brief, there are ten descriptions about riba from the contents of the Quranic passages mentioned in the Holy Quran:

1) Riba is a type of increase in a loan.

2) Taking riba is zulm on the borrower.

3) Depriving the lender of ra's al-mal is zulm.

4) Riba often involved doubling and redoubling of the debt.

5) Charity is an alternative or an opposite to riba.

6) Riba is not like trade.

7) Riba leads to destruction and Sadaqah leads to growth.

8) Dealing in riba is gaining through the wealth of other people.

9) Riba was prohibited earlier for the Jews also.

10) Taking riba is a very serious sin.

\subsection{Trade}

Trade or buyu literally means selling (Ahmad Warson Munawir, 1997). Rachmat Syafe'i (2001) viewed that the trade can also be interpreted as an exchange between two things or two goods or two matters. Technically, trade means a business where the sale price consists of the price of the goods plus the agreed margin (Sunarto Zulkifli, 2003). The Qur'an firmly distinguishes the terms of riba and trade, as is in Al-Baqarah, verse 275, Allah s.w.t. revealed:

"Those who devour usury will not stand except as stand one whom the Evil One by his touch hath driven to madness. That is because they say: "Trade is like usury," but Allah hath permitted trade and forbidden usury. Those who after receiving direction from their Lord, desist, shall be pardoned for the past; their case is for Allah (to judge); but those who repeat (The offence) are Companions of the Fire: They will abide therein (forever)."

(Al Quran [2:275])

The verse explained to us that Islam justifies trade, because trade increases wealth. While Islam has forbidden riba or usury because it contains elements of falsehood gain, Islam orders people to do business or trade on the basis of mutual consent which promises a profit to gain. A hadith says,

"Prophet Muhammad (s.a.w) asked one of his companions on the job (profession) what is best. He then replied: Business man's own hands and every sale that is good"

(HR. Bazzar and Hakim). 


\subsection{Loan}

Loan means a deal between two parties or more regarding a sum of money. In the context of a bank, they give a loan for many purposes such as house loan, study loan, vehicles loan and others. However, under current Conventional banking system one needs to pay back loan with additional amount which is known as interest or riba. Riba is prohibited.

"If the debtor is in a difficulty, grant him time till it is easy for him to repay. But if ye remit it by way of charity, that is the best for you if ye only knew".

\subsection{Charity}

(Al-Quran [2:280])

Charity is opposite to riba in which it will be rewarded by the blessing of the Almighty Allah s.w.t. Charity could be defined as two main good deeds i.e zakat and sadaqah. So, riba and charity are the opposites of one another. This is explained in Allah s.w.t.'s revelation:

"That which you give for Riba in order to increase through the property of (other) people, will have no increase with God. But that which you give as charity (zakah), seeking the Countenance of God (will increase); it is these who will get a recompense multiplied".

(Al-Quran [30:39])

\section{In another verse:}

"Allah will deprive usury of all blessing, but will give increase for deeds of charity: For He loveth not creatures ungrateful and wicked"

(Al-Quran [2:276])

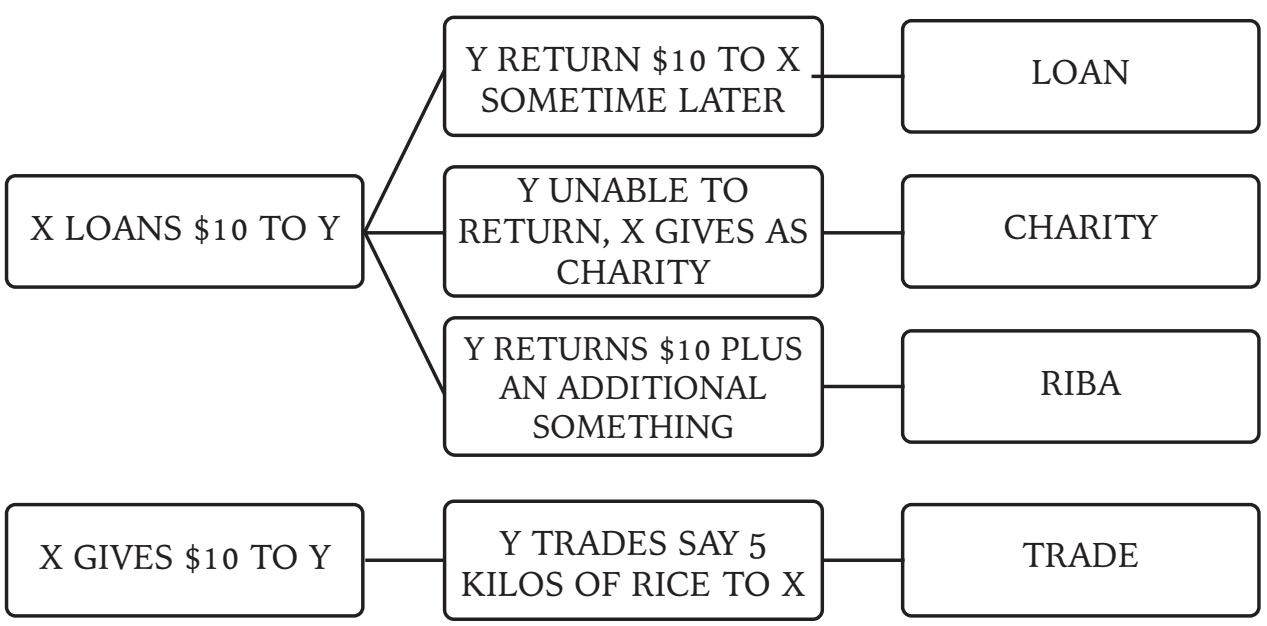

Figure 1.1 A Framework Of The Four Quranic Words 


\section{Conventional Banking}

Conventional bank gives loan where the return is based upon the interest, the prohibited riba (interest based lending) and gharar (speculation or uncertainty). Conventional banking is based on riba which is forbidden in Islam. The term normally adopted in Conventional banking is Interest Rates. Interest rates are intended as a payment for the use of capital borrowed by other parties. In other words, it is time value of money. Interest rate can be of different names such as the interest rate on the loan, deposit rate, treasury bills, security money and others.

In essence, banks take deposit from customers consider for example says at $3 \%$ deposit rate, then lend the money to other customers at $6 \%$ lending rate with a gain of net interest spread of $3 \%$ as shown in Figure 1.2 below. On both sides, it involves riba.

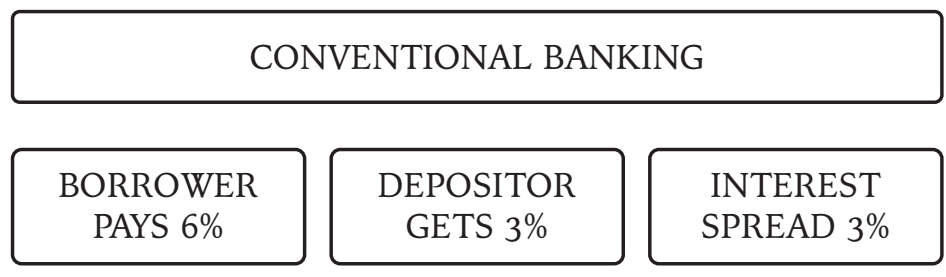

Figure 1.2 Distribution of interest in Conventional Banks

Conventional banks have no other choice but to lend money at a higher lending rate than the deposit rate as they have to pay interest to depositors and to cover its own operating cost and profit. Banks need to pay interest to depositors to attract them to the banks in order to make the system work. Banks conduct their business purely based on profit. From this profit, banks continue to grow in providing various value added financial services by using latest technologies to maintain customer loyalty which leads to the depositors gain at the expense of the borrowers.

Conventional banking acts as the intermediary between depositors market and borrowers market. In the capitalist economic system, the owner of capital has absolute right on capital; therefore, money lenders have the full right to gain interest from borrowers. Bank cost of fund is determined by the amount paid to depositors. The difference between bank interest income from borrowers and bank cost of fund is called interest spread.

For the purpose of illustration Table 1.1 below shows the fincial records based on Audited Account 2015 of the respective banks in Malaysia. Even though Figure 1.2 and Table 1.1 show nothing new, but it is the purpose of this paper to challenge and raise questions as to why depositors have the full right to gain interest in the capitalist economy and as to why depositors are not made to feel obligated to pay zakat in the 
Islamic economy. This is where Islamic economy should take a departure from capitalist economy when the two value systems collied between the "right" of depositors and the "obligation" of depositors. This paper claims that depositors have no "right" to gain interest but rather depositors have "obligation" to pay zakat.

Table 1.1 Conventional banking interest spread 2015

\begin{tabular}{|l|c|c|c|}
\hline \multicolumn{1}{|c|}{ Banks } & $\begin{array}{c}\text { Interest Income } \\
\text { (billion) }\end{array}$ & $\begin{array}{c}\text { Interest Expense } \\
\text { (billion) }\end{array}$ & $\begin{array}{c}\text { Interest Spread } \\
\text { (billion) }\end{array}$ \\
\hline Maybank & 19.7 & 8.6 & 11.1 \\
CIMB Bank & 11.7 & 5.4 & 6.3 \\
Public Bank & 14.2 & 7.8 & 6.4 \\
Hong Leong Bank & 6.1 & 3.3 & 2.8 \\
RHB Bank & 7.9 & 4.6 & 3.3 \\
Affin Bank & 2.3 & 1.5 & 0.8 \\
Alliance Bank & 1.7 & 0.9 & 0.8 \\
Am Bank & 4.3 & 2.3 & 2.0 \\
\hline
\end{tabular}

\section{Islamic Banking}

Islamic banking shares the same concept in financing business for the profit just like Conventional banking that enables the depositors gain at the expense of the borrowers. However, the main difference of Islamic finance and Islamic banking can be attributed to the Islamic idealism where profits come from trade transactions, not from money lending on interest. Islamic scholars claim that Islamic banking is shariah compliant in financing businesses.

It seems that the current system of Islamic banking is an adaptive reform from Conventional banks. Many critics think that the existing adaptive reform is not fully shariah compliant as the outcome of Islamic banking system is similar to Conventional banking where the depositors gain at the expense of the borrowers.

Islamic banking promises that all its products and services offered are in compliance with the shariah principles which gives justice to both; the banks and customers and meet the spirit of Islam. It offers a list of Islamic products for their customers such as murabaha (a sale based instrument), the financing of commissioned manufacturing or construction istinaa and the forward-sale salam.

Next, lease based instruments like ijara are also similar to the traditional leasing with certain distinctions, and equity based financial intermediation which is known as 
mudaraba takes place through profit and loss arrangements (Warde, 2010). In which, Siti Aisyah Hashim et al., (2012) stated that, from the point of ethics, only Bank Islam Berhad, the Islamic bank which is seen to achieve a stability in the payment of zakat because it shows high performance within three consecutive years. Islamic banking while others are in the middle and lower levels. For financing by qard hassan, only seven banks that offer the instruments to customers, and the Asian Finance viewed as having the highest offer for this instrument as compared with other Islamic banking.

As modern banking institutions, Islamic banks operate under Islamic Law (shariah), i.e., the Quran and Sunnah (Van Schaik, 2001), which both strongly emphasise the importance of ethics (Elmelki \& Ben Arab, 2009). Islamic banks often describe themselves as providers of ethical financial services (Wilson, 2005; Saidi, 2009); therefore, the implementation of ethics is explicit in the business of Islamic banks (Wilson, 2005). Kassim et al. (2009), claims that the primary reason why Islamic banking may become more stable as compared to Conventional banking is that they are not affected by the fluctuations on interest rates. Stability in demand for money holds some positive effects in terms of efficiency in monetary policies and the financial stability in the system. On the other hand, Kia and Darrat (2007) refer to two major reasons why interest-free Islamic banks contribute to the stability more than the others.

Islamic banking in essence follows Conventional banking format where the depositors gain at the expense of borrowers. However, Islamic banking avoids direct dealing in riba but does a trade following the Islamic principle, 'trade is halal and riba is haram'. In order to circumvent riba, an interest bearing loan is broken up into two trade transactions even though these two transactions are not independent of one another. For example, it is not possible for an Islamic bank to buy a house from a customer without the customer buying the house back from the bank with a mark-up profit to the bank as illustrated in Figure 1.3 below:

Figure 1.3 Two trade transactions equivalent to one riba transaction

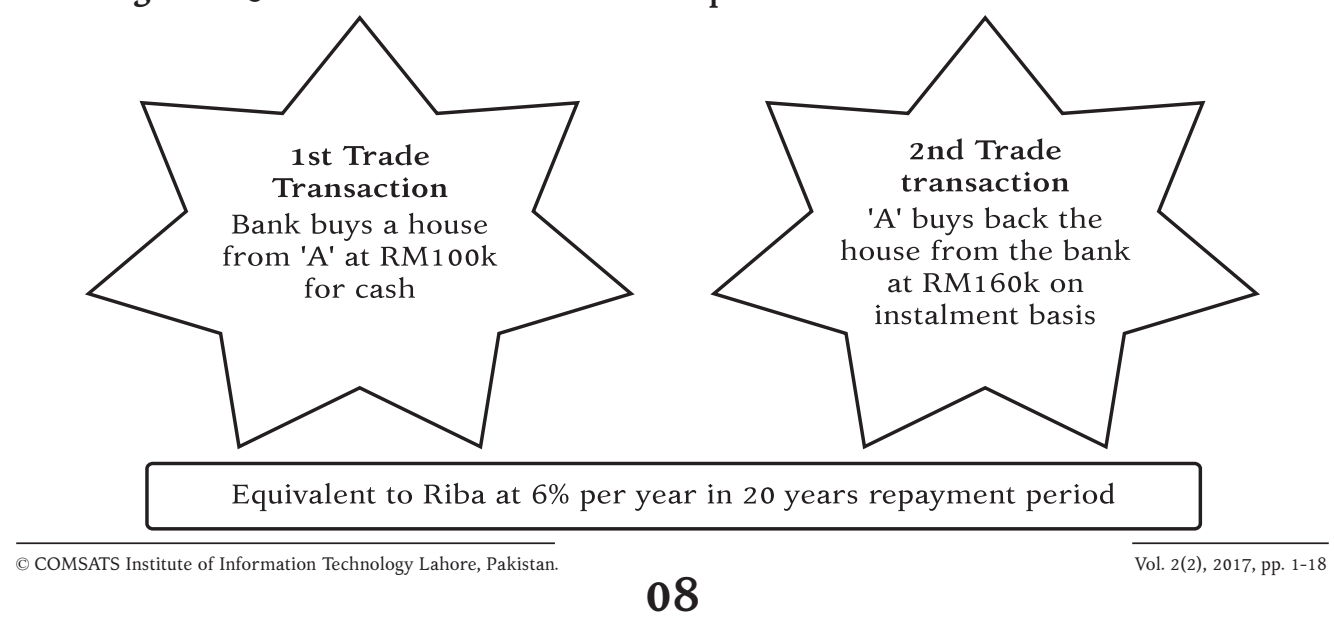


Figure 1.3 above illustrates the two trade transactions that are equivalent to one riba transaction. Since the two trade transactions are not independent, some argue that an Islamic bank is indirectly involved in riba. In fact, in order to compete with Conventional banks, Islamic banks has to ensure that their 'profit rate' is at the same level with 'interest rate'. This is to prevent arbitrage between the two banking systems that offer same product yet at different price point. Again, it seems just a mere change of label. The two trade transactions create an extra legal document for the second transaction yet Islamic banking justifies it by having a $20 \%$ discount on Stamp Duty as the government promotes an Islamic banking.

There is criticism on the present Islamic banking system that some have come to the conclusion that it is just a charade despite being guided by shariah scholars on how to Islamise their products. Islamic banking deceivingly converts riba tansactions into trade transactions and labels itself as traders and not moneylender. Yet, the trade transactions are "mechanically arranged" to eliminate $100 \%$ trading risk because banks are prohibited from trading activities in the first place. Secondly, Islamic banking failed to bring back the concept of qardan hasana which is fundamnetal to Islamic economy.

There are also condemnations out there by some Islamic scholars on current Islamic banking system that devours riba even though they have not offered an alternative. These criticisms and argumentations as well as condemnations should not be taken negatively but as the stepping stone to the proposed Zakat banking.

6. Re-Evaluation on the Concept of Zakat 6.1 Paper Money Has Replaced Dinar (Gold) And Dirham (Silver) As The New Currency

Quranic verses mentioned Dinar and Dirham. In Surah Al-Imran $(3 ; 75)^{(1)}$, Allah s.w.t. accepts the use of Dinar (gold) as valuably regarded as money for any transaction and businesses. Similarly, Dirham (silver) also is accepted by Islam as valuable as money in any transaction and business dealing. For example, in Surah Yusof (Yusof; 20) ${ }^{(2)}$. Thus some views that paper money is not sunnah money. Gold and silver money are the only sunnah money; therefore, people must go back to use gold and silver money. Upon reevaluation of idea regarding the use of gold dinar and silver dirham, one will find that the Prophet (s.a.w) used gold dinar and silver dirham minted by Byzantine Empire, not by the Muslims.

History has showed that gold dinar was not minted by Muslims until about half century after the demise of the Prophet s.a.w. Therefore the reason for not accepting paper money purely on the basis it was created by the western world needs to be reconsidered. 6.2 Like Gold and Silver; Paper money as currency are Zakatable "Islam has been built on five [pillars]: testifying that there is no God but Allah and that 
Muhammad is the Messenger of Allah, performing the prayers, paying the zakat, making the pilgrimage to the House, and fasting in Ramadan"(Bukhari \& Muslim). In these five pillars of Islam, zakat is the third. While gold and silver are two valuable items that are zakatable because they were used as money such as dinar and dirham since ages. Gold and silver were zakatable not because they were merely gold and silver, but rather they were used as currency or as a medium of exchange. The intrinsic value of gold and silver was in their usage.

Nowadays, all the countries are using paper money that has replaced the use of gold and silver as currency or as money. Since gold and silver are subjected to zakat; therefore, paper money is also subjected to zakat. Almost all money is deposited in the bank in the owners account that worth billions. This paper attempts to make it obligatory to the depositors to pay zakat based on the amount in the bank account subject to nisab. Even if a person borrows money and deposites in the bank, this money is subjected to zakat. This zakat system discourages unnecessary borrowing and promotes earlier settlement of debt when a person has extra cash. On the other hand, shares and investments should not be made zakatable. Although they have monetary value, yet they are not real money or currency.

\subsection{Paying Zakat as Frequent as Salat}

The author in this article is re-evaluating the important subject that is still not been given enough attention which is paying zakat should be done more regularly instead of once a year. In fact, zakat is mentioned along with salat many times in the Holy Quran repeatedly saying that:

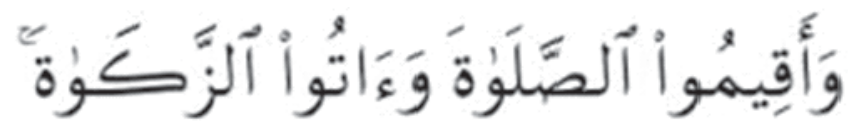

This verse shows that these two elements in the five pillars of Islam seemingly cannot be separated, in which salat (prayer) is not perfect without performing zakat, and performing zakat only without performing salat, is not perfect. moreover, zakat must be paid by the Muslim as they perform salat in their daily life. Zakat is akin to salat and as salat is performed regularly, so we may interpret moreover, we also need to pay zakat regularly instead of once a year as we normally practice now.

Thus, the author of this article again is re-evaluating about performing salat and performing zakat regularly. The current views that haul is one full year, so Muslims need to pay zakat only once a year. Yet it is not practical nowadays since money in the bank is an on-going concern and is continuously fluctuating, we should pay zakat regularly by calculating 'nisab' on month to month of the following year. We need to calculate on the monthly rest basis as the amount is constantly changing. So, as all 
Muslim know that zakat haul is one year at the rate of $2.5 \%$ per annum, yet zakat on money or saving in the bank as shown in table below should be calculated on monthly basis.

Month to month of the following year one complete year.

Table 1.2 Zakat on Going Concern Concept an example

\begin{tabular}{|l|l|l|l|}
\hline \multicolumn{1}{|c|}{ Month } & Year $\mathbf{1}$ & Year 2 & Year 3 \\
\hline Muharam & 20,000 & 12,000 & 28,000 \\
Safar & 15,000 & 15,000 & 23,000 \\
Jamadil Awal & 27,000 & 23,000 & 12,000 \\
Jamdil Ahkir & 28,000 & 45,000 & 10,000 \\
Rabial Awal & 12,000 & 34,000 & 15,000 \\
Rabial Akhir & 12,000 & 18,000 & 21,000 \\
Rejab & 14,000 & 13,000 & 13,000 \\
Shaban & 18,000 & 13,000 & 14,000 \\
Ramadhan & 23,000 & 20,000 & 23,000 \\
Syawal & 15,000 & 22,000 & 23,000 \\
Zulhijjah & 12,000 & 13,000 & 14,000 \\
Zulkaidah & 24,000 & 26,000 & 26,000 \\
\hline
\end{tabular}

Haul is a cycle of one year but since money in the bank is being concerned, the costumers should pay zakat on monthly rest by calculating nisab from month to month of the following year. They need to calculate on the monthly rest basis as the amounts keep changing, whereas at the end, they find that they are paying zakat monthly. This means that Muslims can pay zakat on monthly rest at the rate of $2.5 \%$ per annum divided by twelve (12) months, so zakat is made frequent as performing salat. This idea and suggestion of monthly zakat or even daily basis (by dividing the rate $2.5 \%$ by 365 days) is good for the Muslims individually in fulfilling their duty and it is also good for the economy especially for Muslims' economy. Should he die he knows his zakat has been duly collected that day.

\subsection{Loan Create Money Even If Gold And Silver Were Used As Currency}

Loan means to give ownership of some part of property to others that should be returned similar without any increase. Since lender separates some parts of his property to give it to debtor, here loan means to cut and separate (Alkhan Mostafa, 1982). Loan is mentioned in the Holy Quran in the longest verses. This re-evaluation views the fact that Allah s.w.t. knows that loan creates money; therefore, Quran addresses it by delivering longest verses in Surah Al-Baqara; 282, it says that:

"O you who have believed, when you contract a debt for a specified term, write it 
down. And let a scribe write [it] between you in justice. Let no scribe refuse to write as Allah has taught him. So let him write and let the one who has the obligation dictate. And let him fear Allah, his Lord, and not leave anything out of it. But if the one who has the obligation is of limited understanding or weak or unable to dictate himself, then let his guardian dictate in justice. And bring to witness two witnesses from among your men. And if there are not two men [available], then a man and two women from those whom you accept as witnesses - so that if one of the women errs, then the other can remind her. And let not the witnesses refuse when they are called upon. And do not be [too] weary to write it, whether it is small or large, for its [specified] term. That is more just in the sight of Allah and stronger as evidence and more likely to prevent doubt between you, except when it is an immediate transaction which you conduct among yourselves. For [then] there is no blame upon you if you do not write it. And take witnesses when you conclude a contract. Let no scribe be harmed or any witness. For if you do so, indeed, it is [grave] disobedience in you. And fear Allah. And Allah teaches you. And Allah is Knowing of all thing"

Montesquieu (2004) in his book "Rouh al-Qavanin" stated that "Lending interest free loan to others is one of the best deeds, the act that is recommended in different religions, a moral deed, not a law or culture of a country or society". He also added that "Interest free loan is one of the recommendations of divine religions. It is recommended by all prophets and its presentation in holy books indicates its ancient history". Although he believes that loaning is a moral not legal deed, but most of us believe that is not only a moral principle, but it can be considered as a part of economic system; along with other parts of a healthy economy, it can help and control needy people of the country and society.

This seems to be agreed with the re-evaluation idea of giving loan without riba. Since money has been created in the economy in the form of future obligation, there should be no riba, and this is the reason why riba is prohibited. Thus, the relationship between riba and loan becomes one of the ideas to rethink by the author, in which loan has an additional rate of interest according to the length of years of the contract between the borrower and the bank. Allah s.w.t. knows that loan creates money; therefore, Quran discusses and elaborates it in the longest ayat. Since money is created in this way; therefore, it is prohibited (haram) to charge the interest. One of the verses is as below:

"If the debtor is in a difficulty, grant him time till it is easy for him to repay. But if ye remit it by way of charity, that is best for you if ye only knew."

According to Bank Negara Malaysia publication, as at October 2016 the amount of currency in circulation is only RM 80 billion, yet the report also showed that amount of demand deposit is RM 280 billion, saving deposit is RM 140 billion, fixed deposit is RM 
760 billion, foreign currency deposit is RM 130 billion and other deposit is RM 215 billion (the figures have been rounded off for simplicity) respectively. All of these deposits were created through loans by the banking system. One can assume that even the currency in circulation is actually real gold instead of paper money in ringgit denomination but because of loans by the banking system new money in the domination of dinar or dirham will be created by the same amount.

Table 1.3 Amount Of Money Created by Malaysia Total Banking System

\begin{tabular}{|l|l|}
\hline Currency in Circulation & RM 80 billion \\
\hline Demand Deposit & RM 280 bilion \\
Saving Deposit & RM 140 bilion \\
Fixed Deposit & RM 760 billion \\
Foreign Currency Deposit & RM 130 billoin \\
Other Deposit & RM 215 billion \\
\hline
\end{tabular}

\section{Zakat Banking}

\subsection{Social Value of Zakat}

Literally, zakat means growth, purification and righteousness. Al-Shaukani gives the following definition: "linguistically, zakat means growth: One says zakat 'haz-Zar' meaning the plant grew. It can also mean purification. In shariah (Islamic Law) it implies both meanings. The first meaning is construed as to cause growth in wealth, or as to cause more reward or as to pertain to increasing wealth, such as the case in commerce and agriculture" (A.R. Ansari, N.d). Zakat is the third pillar of Islam after reciting the shahadah and the five daily prayers. Zakat started to be compulsory on Muslims since the time of the Prophet s.a.w., which was in the month of Shawwal in the second year of His migration to Medina (Ahmad Syafii, 2005).

The benefits of performing zakat are priceless for the development of ummah especially in terms of their economic survival in this modern time. Zakat is used as a mechanism to help Muslims in need and the collection of the zakat becomes as a charity to help the recipients of zakat. Some of the specific property of the persons who entitled to zakat will be taken and distributed to those recipients who deserve it. Here, zakat has a role to nourish feelings of love for the brothers and sisters in Islam and help them to survive. This indirectly reduces feelings of jealousy and envy among the recipients to their rich Muslim brothers and sisters, while the community will live in peace and harmony.

There are eight groups of eligible recipients of zakat as was decided by the religion of 
Islam, namely the very poor, poor, zakat collector (Amil), convert (Muallaf), for freeing slaves, those who are in debt, those on the path of Allah (Ibn sabil) and those who are traveling (traveller).

\subsection{Economic Value Of Zakat}

The focus on the aspect of the collection of zakat has received much attention from researchers in the field of zakat (Kamil and Ahmad Madzhan, 2002; Zainol, 2008; Ram Al Jaffri, Zainol, Md Kamil \& Hairi, 2008). The study by Musa et al. (in the excerpt of Abdul Ghafar \& Hailani 2006) has viewed about the measurement of zakat offices performance in Malaysia, where several states has contributed to the studies in investigating the effectiveness of the governance aspect of the distribution of zakat funds in their respective states.

This article hopefully is to be the first research to focus on the potential value of zakat. It shows the potential value of zakat from monetary sectors are very much bigger than the potential value of zakat from traditional sectors such as zakat fitra, zakat on agriculture and zakat on farming as shown in table below.

The statistics are based on Malaysia total figures of Malaysia including ownership by Non-Muslim to see the economic impact. After all Muslim's ownership figures are not available. These figures show that zakat can play a major role in the main stream economy once monetary elements either cash or bank deposit are made zakatable. Relying on tradition sources of zakat will have limited economic impact.

Table 1.4 Potential Zakat Value In Malaysia Including Non-Muslims Ownership

\begin{tabular}{|l|l|c|c|c|c|c|}
\hline Type of Zakat & Unit & $\begin{array}{c}\text { Total } \\
\text { Quantity }\end{array}$ & Rate & $\begin{array}{c}\text { Quantity } \\
\text { Zakat }\end{array}$ & $\begin{array}{c}\text { Value per } \\
\text { unit (RM) }\end{array}$ & $\begin{array}{c}\text { Zakat } \\
\text { Value (RM) }\end{array}$ \\
\hline Fitra & person & $30 \mathrm{mil}$ & & & 7 & $210 \mathrm{mil}$ \\
Padi & ton & $2.6 \mathrm{mil}$ & $5 \%$ & 130,000 & 1,200 & $156 \mathrm{mil}$ \\
Cattle & head & $0.9 \mathrm{mil}$ & 1 per 30 & 30,000 & 5,000 & $150 \mathrm{mil}$ \\
Goats & head & $0.6 \mathrm{mil}$ & 1 per 40 & 15,000 & 800 & $12 \mathrm{mil}$ \\
Money in Circulation & ringgit & $80 \mathrm{bil}$ & $2.5 \%$ & na & na & $2.0 \mathrm{bil}$ \\
Demand Deposit & ringgit & $280 \mathrm{bil}$ & $2.5 \%$ & na & na & $7.0 \mathrm{bil}$ \\
Saving Deposit & ringgit & $140 \mathrm{bil}$ & $2.5 \%$ & na & na & $3.5 \mathrm{bil}$ \\
Fixed Deposit & ringgit & $760 \mathrm{bil}$ & $2.5 \%$ & na & na & $19.0 \mathrm{bil}$ \\
\hline
\end{tabular}

7.3 The Role of Zakat Banking

Zakat banking has three main roles: 


\section{i) Providing the routine financial services}

First and foremost Zakat banking will continuously provide the routine financial services. Zakat banking would charge on competitive basis for the various value added financial services such as money withdrawal, money transfer, account keeping etc. From these activities, the banks should have made profit without relying on the riba base of interest spread between borrower rate and depositor rate as Conventional banking does.

\section{ii) On depositors side Zakat bank acts as Amil of zakat}

A Zakat bank should act as Amil which is entitled for $1 / 8$ of zakat collection. Here, the bank takes deposit from the depositors who agree to pay zakat from his deposit as a religious duty. The depositors will not get a return from their deposited money from the bank anymore (which is Riba). Then, the bank will calculate zakat proportion from the deposited money and credit it to the Zakat Authority every month for the distribution to the Asnaf. Almost all Muslims will be happy to give a donation anyway, so why don't they pay zakat through the bank which is easier, secure and comfortable. Although the rate for zakat is $2.5 \%$ per annum; but it can be made payable on monthly rest or even daily rest as we are in the digital age in order to make zakat as regular as salah.

It is important at this juncture that the writer strongly proposed that any amount of zakat paid by depositors are deductible from taxable income within the purview of Income Tax. In this manner zakat paid is considered as expense for either individuals or corporations.

\section{iii) On borrowers side Zakat bank give qardan hasana}

Zakat bank will be able to give interest free loan. The risk management process of loan approval and collection should be continued as the Conventional banking or Islamic banking best practices albeit the interest element.

Many ayat in the Quran mention about qardan hasana. One example is "And establish prayer and pay zakat. And loan to Allah a beautiful loan." [Sûrah al-Muzammil: 20]. A beautiful loan is a loan that is provided without charging any return or profit or interest. If a return in any form is associated with the loan, it will not be a qardan hasana. The difference between qardan hasana and sadaqah (charity), is that qardan hasana has to be repaid, although the borrower specifies the time of repayment, while sadaqah is pure charity. It is reported from the Prophet s.a.w. that the reward by Allah s.w.t. for sadaqah is ten times and that of qardan hasana is eighteen times, thus underlining the importance of qard hasana. In the final analysis, Zakat Banking will prevent the depositors gain at the expense of the borrowers.

\subsection{The proposed Tax Rebate under Malaysian Income Tax system}

At present only an individual is given tax rebate on zakat paid but not for a company or 
corporation who actually owns substantial amount of deposits in the banking system. Therefore, to make this system work it is proposed that a company should be given same tax treatment as an individual. Based on the figure in Table 1.3 above and not withstanding economic dynamics it is estimated that zakat on currency will ammount to RM 32 billion per annum. Assuming tax rebate is actually being given, the Income Tax collection would be reduced from RM 112.4 billion to RM 80.4 billion. However, by the same token Government spending in the area covered by zakat Asnaf can be cancelled out. These assumption figures maybe simplistic yet they are realistic concept for Zakat banking to work on where it benefits depositors and borrowers while the Government and Zakat banking facilitate the processes.

Table 1.4 Malaysian Government's Budget 2017.

\begin{tabular}{|c|c|}
\hline Federal Government Income 2017 (budget) & RM (billion) \\
\hline Income Tax & 112.4 \\
Indirect Tax & 59.7 \\
Borrowings & 41.2 \\
Non-Tax & 39.1 \\
Other-Tax & 8.3 \\
Total & 260.8 \\
\hline
\end{tabular}

\section{Implementtion Stratyegy; Saidina Uthman'a Well Story}

Saidina Uthman's r.a. well story is one of the famous stories. Fortunately, we can apply and use the logic of this story in our implementation strategy in combating riba in banking by synthesising zakat into qardan hasana.

The story is;

"In Medina, water was scarce. There was a well owned by a Jew who charged high price for his water. Saidina Uthman (R.A) offered to buy the well but the Jew declined. Because he was a skilful trader and negotiator, he negotiated a price for half the well; he would have control one day and the owner the alternate days. Saidina Uthman R.A. gave out his water to the Muslims freely, leaving the Jew with no customer on the alternate days. The original owner of the well had no choice but to sell his half of the well to Uthman who nevertheless paid a fair price for it"

Our quest is to find someone or some institution like Saidina Uthman (R.A) to start Zakat banking by "buying the half the well" and giving loan at zero interest. Sooner Conventional banking will lose all of its customers as nobody wants to borrow money 
with interest.

When nobody borrows from Conventional banks then Conventional banks cannot afford to pay interest to depositors, and soon will lose all of its depositors too. Conventional banks then will have no choice but to convert to Zakat banking. By doing so, zakat is placed in the main stream of economy and fulfills our belief that Allah (s.w.t) deprives riba and increases charity.

\section{Conclusion}

It is clear from the discussion above that when depositors pay zakat on their deposit in the bank, its enables the bank to give loan at zero interst rate qardan hasana. As Muslims we believe that performing zakat will purify, increase and sweeten our wealth. On top of it, Zakat banking system will enable qardan hasana which we know is many times better than the act of charity.

Economically, Zakat banking will also solve the finacial crisis in the long term. Financially, those zakat payers will save their Income Tax by getting tax deduction on the amount paid for zakat as the zakat money will go to the Asnaf. The government budget will also enhanced as the amount of zakat from currency will be sizeable to play its role in the economy.

The vision of this paper is to move the present Islamic banking adaptive reform to Zakat banking transformational reform by year 2020 in a new banking model where depositors pay zakat and borrowers enjoy qardan hasana.

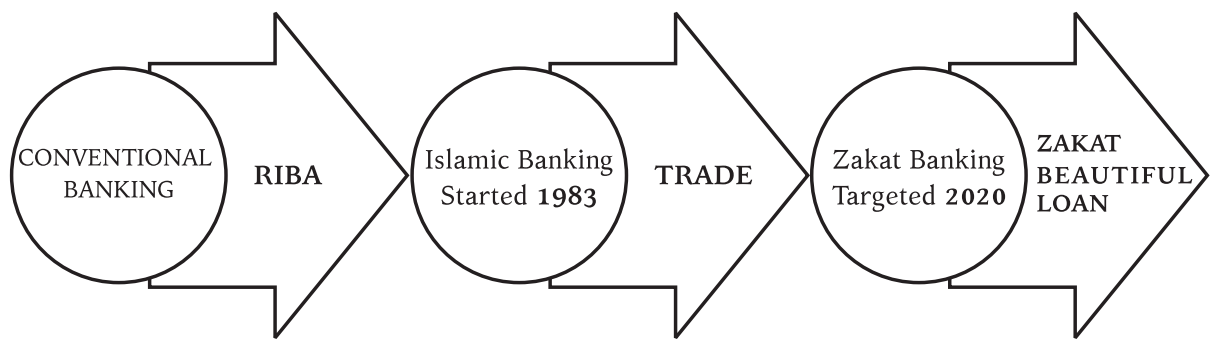

Figure 1.4; Zakat banking In Year 2020

The writer of this article imagines the new and brave change from the present Islamic banking system to the future Zakat banking for the benefits of the ummah.

\section{References}

"Zakat banking is the cornerstone in reviving Islamic economic system".

Abu Bakar Bin Abi Syibah, Abdullah Bin Muhammad Bin Ibrahim Bin Usman Bin Khawasiti alAbbasy, kitaabu al-musnaf fii al-ahaadits wa al-atsaar (Riyad: Maktabah al-Rusd: $1409 \mathrm{H}$ ), cet.1, Jilid 4, 554 . 
Ahmad Hidayat Buang. (2009). Jurnal Muamalat. Pengurusan Harta Keluarga mengikut Islam dan Realiti Semasa Di Malaysia. Bil. 2. Putrajaya: Jabatan Kemajuan Islam Malaysia (JAKIM).

Ahmad Syafi'i, K. (2005). Siri keajaiban rukun Islam: Hikmah zakat. Kuala Lumpur: Jasmine Enterprise.

Ahmad Warson Munawir, Al Munawir Kamus Arab-Indonesia (Surabaya: Pustaka Progesif, 1997), 124.

Abdul Ghafar, I. \& Hailani Muji, T. (2006). Zakat: Pensyariatan, perekonomian dan perundangan. Penerbit UKM: Bangi.

Alkhan Mostafa, A., Alfeqh al-monhaji ala mazhab alemam al-shafei, vol. 6, p. 101.

Azlina Zainal Abidin, Tamat Sarmidi, Abu Hassan Shaari Md Nor (2013) Jurang pendapatan dan hutang isi rumah. (Tesis Sarjana). Universiti Kebangsaan Malaysia, Malaysia .

Elmelki, A., \& Ben Arab, M. (2009). Ethical investment and the social responsibilities of the Islamic banks. International Business Research, 2, 123-130.

Emas dan Perak daripada perspektif Islam. 2011. http://mygold77.blogspot.my/2011/03/emasdan-perak-dari-perspektif-al-quran.html.

Hadis-Hadis Yang Berkaitan Emas. 2010. http://superbikesboyz.blogspot.my/2010/11/hadishadis-yang-berkaitan-emas.html.

Kamil, M.I., \& Ahmad Mahdzan, A. (2002). Peranan sikap dalam gelagat kepatuhan zakat pendapatan gaji. Analisis, 9(1\&2), 171-191.

Kassim, K. M., Bahari, A., Kassim, N., Rashid, Nik, R. N. A., \& Jusoff, K. (2009). Retaining customers through relationship marketing in an Islamic financial institution in Malaysia. International Journal of Marketing Studies, 1(1), 66-71.

Montesquieu, S. (2004). Spirit of the laws, translated by Mohtadi, A.A., informing and library.

Rachmat Syafe'i, Fiqih Muamalah (Bandung: Pustaka Setia, 2001), 73.

Ram Al Jaffri, S., Zainol, B., Kamil, M.I., \& Md Hairi, M.H. (2008). Gelagat kepatuhan zakat perniagaan: Aplikasi teori tindakan beralasan. Kertas kerja dibentangkan di National Management Conference, Terengganu.

Saidi, T. A. (2009). Relationship between ethical and Islamic banking systems and its business management implications. South African Journal of Business Management, 40(1), 43-49.

Shafiq (2014). Akaun, Harta Milik Khalifah Saidina Uthman Affan Masih Wujud Hingga Kini. Shafiqolbu.Wordpress.Com. https://shafiqolbu.wordpress.com/2014/12/15/akaun-hartamilik-khalifah-saidina-uthman-affan-masih-wujud-hingga-kini/

Sunarto Zulkifli, Panduan Praktis dan Transaksi Perbankan Syariah (Jakarta: Zikrul Hakim, 2003), 39.

Tafsir Ibnu Kathier jilid 4, 2007.

Van Schaik, D. (2001). Islamic banking. The Arab Bank Review, 3(1), 45-51.

Wilson, R. (2005). Parallels between Islamic and ethical banking. Journal of Islamic Banking and Finance, 22(3), 85-97.

Zakah by Abdul Rehman Ansari. Published by IPCI, 481 Coventry Road, Small Heath, Birmingham B10 0JS. p. 5 .

Zuraini Anang, Roshanim Koris \& Roseliza Mat Alipiah (2004). Perbankan Islam Dan Penerimaan Masyarakat Di Terengganu. 4th International Malaysian Studies Conference; 35 August 2004, Universiti Kebangsaan Malaysia, Bangi. 